\title{
EMPOWERMENT THROUGH ICT: A CRITICAL DISCOURSE ANALYSIS OF THE EGYPTIAN ICT POLICY
}

\author{
Bernd Carsten Stahl \\ De Montfort University, UK
}

\begin{abstract}
ICT is often promoted as a solution to a range of social ills. This is particularly true for the use of ICT in developing countries. ICT deployment can address numerous issues but its overall aim is the empowerment and emancipation of individuals with the aim of improving society. This chapter takes a critical approach to such discourses and asks which claims to emancipation are raised and how they are underpinned. Using a Habermasian framework, the chapter undertakes a critical discourse analysis of the Egyptian ICT policy. This important document, which has inspired much African ICT policy, is analysed to identify the validity claims it raises. These claims, many of which are explicitly aimed at emancipation and empowerment, are then contrasted with social realities as well as the overall structure of the policy document. This comparison shows that empowerment is not only not achieved, but arguably not a primary aim of the policy in the first place. Instead, claims to empowerment are used to legitimise particular aims which conflict with empowerment. The chapter concludes with a critical reflection of the chosen approach and findings.
\end{abstract}

Keywords: Information society, policy, ICT, social movements, institutions

\section{Introduction}

Governments and international agencies spend huge amounts of money on projects aimed at promoting the use of information and communication technology (ICT) in so-called developing countries [61, 63]. The immediate aim of such investment is typically economic growth [50, 79]. It is usually recognized, however, that economic growth is no end in itself. Economic growth is meant to produce employment, create welfare, and improve the lot of all members of society. Its purpose is to allow people to live a fulfilled life according to their own design. Briefly, the final aim of the promotion of ICT in developing countries is the empowerment of the members of society.

This chapter will shed doubt on the empowering effect of ICT. It will do so by undertaking a critical discourse analysis of the Egyptian Information Society Policy. This policy document is of pivotal importance having been presented by 
Egypt at the World Summit on the Information Society and having inspired numerous comparable policies across the African continent. The discourse analysis will be based on some of Jürgen Habermas' ideas. I will use this approach to focus on two important areas of possible empowerment: political participation and education. The result of the analysis is that ICT has disempowering effects which are known to the agents involved and arguably intended from the outset. The chapter ends with a reflection on the findings and the methods employed.

\section{Critical research in IS}

Critical research is often seen as the third possible research approach, as an alternative to positivist and interpretive research [22, 68]. I believe that this categorization of three research "paradigms" is misleading because it wrongly suggests that the paradigms are mutually exclusive and that they constitute all possible choices. Instead, I suggest a definition of critical research according to critical intention and critical topics and the resulting choice of theory [74, 75], all of which will be discussed below. The extensive debate on critical research has found its way into the field of Information Systems, where a number of special journal issues and books evidence that it is becoming increasingly recognized [45].

\subsection{Critical intention}

The term "critical research" usually stands for research that is grounded on the assumption that society can and should be improved. At the basis of this assumption one can find Marx's view of history as a series of class struggles [57] and a corresponding conflictual view of society [43]. ${ }^{1}$

Critical research is built on the tenet that realities are socially constructed but that they often become reified and objectified. Critical researchers do not simply accept the status quo as the best possible world; they want to know what is "wrong with the world rather than what is right" [83, p. 112]. They aim to open up discursive closure, to facilitate new descriptions and to initiate new discourses [1]. Critical research wants to challenge accepted realities and promote resistance. It cannot be comfortable; it disturbs the quiet and challenges established authorities.

\subsection{Critical topics: Empowerment and emancipation}

The critical intention is mirrored by the choice of research topics, theories, and methodologies. Critical research concentrates on those topics that promise a chance of redeeming the critical intention. The typical topics of critical research

\footnotetext{
${ }^{1}$ One could call this view of critical research with its emphasis on the Marxist roots the "continental European" perspective of critical research. As Harvey [40] points out, there is a different tradition of critical theory in the Anglo-American world. I will concentrate on the European tradition, which should not be misunderstood as implying that all critical research is of a Marxist nature.
} 
are thus power, empowerment, and emancipation [16, 44]. Power is usually perceived as a pervasive influence on human action, rather than straightforward projection of political or military potency [62]. Critical researchers are interested in how power is created and legitimized. The aim of studying power is to identify those who are dominated and to help them represent their claims better, to empower themselves [56, 18, 26].

Another concept related to power and empowerment and central to critical research in IS is emancipation $[2,3,42,66,81,20,82,59]$. The idea of emancipation is to "help eliminate the causes of unwarranted alienation and domination and thereby enhance the opportunities for realizing human potential" [48, p. 69]. Emancipatory concerns are frequently linked to concepts that appear to hinder emancipation such as alienation [68] authenticity [69], identity [35] or a limited rationality $[54,17,71,82,23]$. Critical researchers in IS have investigated matters of power and empowerment in systems failure [88], the digital divide [52] or gender issues in IS [51].

In this chapter I will use the terms "empowerment" and "emancipation" synonymously. The main concern is to see whether ICT is used for purposes of empowerment. Answering this question raises considerable theoretical problems. The above definition of empowerment as the avoidance of domination, alienation, subjugation, etc. has some intuitive appeal. However, it is difficult to translate into practice. Who is to define what constitutes an empowering practice? Can we as academics prescribe people to be empowered? And what are we to do if their views differ from ours? The solution to this intricate problem may be to look at the research subjects' claims to empowerment. Rather than making material suggestions, we follow the procedural idea that people need to define their own understanding of empowerment (see [76]). My analysis of empowerment through ICT is thus based on the view of Egyptian politicians, administrators and users.

The concept of emancipation is of particular importance with regards to development, as development seems to promise the overcoming of oppression and alienation. It is relatively easy to see how a relationship between emancipation and democracy could be construed where the participative aspects of democracy are constitutive of emancipatory developments. The contemporary debate about empowerment and participation in the development literature is considerable [13, $14,72,87]$ and this chapter does not do it justice. This is justifiable because the chapter does not inquire into substantive emancipation but only aims to identify the role that emancipation plays in ICT policy and whether assumptions and rhetorical devices bear critical scrutiny.

\section{Critical theory: Habermas's discourse}

There are a large number of theories employed by critical scholars. In the continental European tradition there tends to be an explicit link of critical theories to Marxism. The most prominent examples of this are the theories developed by the so-called Frankfurt School of critical research, which is linked to names of its 
members such as Horkheimer, Adorno, Marcuse, and others. Their theoretical approaches were further developed by the second and third generation of critical scholars including Habermas, Apel and Honneth. It is relatively uncontentious to state, however, that other theoretical developments can also lay claim to being critical in the sense of the word suggested here. These include theories such as postmodernism, postcolonialism, or poststructuralism. Prominent critical theorists whose work has been used in IS include Foucault or Bourdieu [12, 53].

I do not wish to engage in a debate on the merits of the respective theoretical approaches. I believe that all of them have the potential to contribute to the critical intention of promoting emancipation. Some explicit observations on Habermas's theory will be necessary to render the chosen methodology understandable.

Rationality is a central concept for Habermas. It represents a disposition to give reasons for one's actions. This can best be understood in the framework of his Theory of Communicative Action (TCA) [38,39]. The anthropological basis of this theory is that we are intrinsically social beings who require social interaction to survive and thrive. Communication is aimed at facilitating cooperation. Communicative action stands for those pieces of communication where the speakers mutually respect each other as autonomous moral beings. Whenever we communicate, each utterance carries several validity claims: those of truth (Wahrheit), legitimacy (Richtigkeit), and authenticity (Wahrhaftigkeit). A further condition of successful communication, which in English-language literature is often counted as a fourth validity claim, is that of clarity or comprehensibility.

It is part of the nature of communication that we do not always agree on the validity claims of all utterances. If this is the case, then discourses take place. Discourses are acts of communication that aim at clarifying contentious validity claims. Discourses are characterized by the attempt to emulate the so-called "ideal speech situation", where the only criterion that will decide their outcome is the quality of the argument [37]. The ideal speech situation is never realised in discourses but it is a necessary condition of the possibility of discourses.

The Habermasian framework has been widely read and applied in IS [49]. Communicative action requires speakers to accept the fundamental equality of others and is thus intrinsically ethical. In IS research these ideas have been applied in two major directions: a critique of research methods and approaches and the attempt to create more "socially informed" methods and theories [55, p. 164]. The latter aspect, the attempt to use Habermasian discourse theory to inform practice, is closely aligned with the critical intention to change current practices and to emancipate users of IS. This ethical ideal is linked to the ideal speech situation, which is taken as an normative ideal used to model reality [9, 81].

Examples of Habermasian research in IS range from fundamental explorations of the impact of ICT on communication [31] to applied considerations of how IS development processes can be improved [29, 81]. The areas of application of these thoughts range from e-government / e-democracy [41] to e-teaching / e-learning [73] and the definition of the field of the field of information systems [42]. 
The attempt to base research on Habermas's theories can also produce problems. There is the egalitarian assumptions that all stakeholders should be equal and the resulting bias toward participatory approaches, which often runs counter to capitalist hierarchies [46]. There are the intricacies of language and the problem of meaning, which a Habermasian researcher must take seriously [19]. Furthermore, there are also fundamental and conceptual problems with the application of Habermas's theories in organisational practice. Chief among them is the dichotomy of ideal and real discourses and the resulting question of the theoretical status of real discourses.

\section{Critical methodology - A Habermas inspired discourse analysis}

There is no generally recognized critical methodology [60]. Part of the reason for this is the nature of critical research, which, by definition, cannot consist of the "application" of a theory to a given situation. I will briefly outline the methodological approach chosen for this research.

In order to identify contradictions between rhetoric and reality in the Egyptian ICT policy, I decided to undertake a critical discourse analysis (CDA) (cf. [32, 33, $34,21]$ ) using a Habermasian framework. Examples of CDA in the literature (cf. $[35,80])$ demonstrate a central problem of the method, namely that it requires extensive discussions of the text. Since I intended to analyze a whole policy framework, this would not have been feasible in a research chapter.

I therefore decided to follow a novel way of doing critical discourse analysis, pioneered by Cukier et al. [24, 25]. This method is based on Habermas's validity claims [55]. It aims to identify these claims, using quantitative and qualitative measures, and thereby explicate the hidden assumptions of texts and discourses. Validity claims are discovered and coded by using a guiding question for each of the four claims: truth, legitimacy, sincerity, and clarity. To help identify claims, I followed the guiding questions put forward by Cukier et al. [22, 23]. Drawing on these questions, texts were coded and validity claims in each text were determined. During the coding several individual claims were noted as frequent and worthy of their own category or sub-category. The main advantage of this approach to critical discourse analysis over traditional methods is that it allows the analysis of a larger body of texts.

The method was applied to the Egyptian Information Society policy. The policy documents can be accessed from the Ministry of Communication and Information Technology's (MCIT) homepage (http://www.mcit.gov.eg/index.asp) under the link "E-Bridges".

MCIT was chosen because it is the government department responsible for ICT. It is also the trendsetter among the Egyptian ministries and the organisation primarily responsible for policy and implementation of ICT in Egypt. The ICT policy is of high importance in Egypt and is supported by President Mubarak. MCIT was set up in 1999 to realize the National Project for Technology 
Development [27]. External business observers view MCIT as a reliable partner and a forerunner of reform in the Egyptian administration [5]. A clear sign of the internal importance of MCIT and its aim of furthering ICT use in Egypt is the fact that its first minister, Dr. Ahmed Nazif, was promoted to the position of Prime Minister in August 2004.

It was decided to use the online version of the policy rather than the full text, on the assumption that it would have been possible to update it and thus reflect current changes. The online version consists of 43 web pages with a length varying from $1 / 2$ to 10 pages when printed out. It gives an overview of the intended use of ICT in Egypt and its contribution to the information society in general. The seven most important policy areas, including e-business and e-government, are outlined in five web pages each, which discuss the intention, principles, implementation, current state, and planned action for each. I identified a total number of 1247 validity claims. In the following data analysis, I describe the findings stemming from these documents. References in curly brackets \{\} refer to the different texts. The exact references can be found in [74], Appendix B.

\section{ICT and empowerment in the Egyptian ICT policy}

In this section I present and discuss the findings of the CDA. I will start by identifying claims to empowerment through the use of ICT in two areas: democratic participation and education. Subsequent to the presentation of the claims, I will discuss the results of the discourse analysis and, where appropriate complement this by alternative descriptions of social reality.

\subsection{Democracy and participation}

In one of the central speeches promoting the ICT effort in Egypt, the Egyptian President Hosni Mubarak [64] said that the purpose of information technology is to facilitate a "better living to all the Egyptians". A similar reference to "enhancing the quality of life for each and every Egyptian" was repeated by the President [65]. Empowerment of the Information Society is the explicit aim of Information Society Development Office, an organisation charged by MCIT with promoting the information society (ISDO, 2005). All of this suggests that empowerment is indeed a central aim of the use of ICT.

This empowering idea is repeated throughout the policy document. The information society, which is the centre of attention of the ICT policy, is said to be a society where "citizens are empowered [...]" $\{2\}$. Different aspects of the policy empower different stakeholders such as the Egyptian IT community $\{17\}$. The empowerment includes participation and explicitly mentions that ICT will allow "genuine participation of citizens, including traditionally marginalized segments of the population" $\{2\}$. Two groups discussed specifically are women where ICT training is meant to "close the gender gap" $\{17\}$ and "enhance the role of women 
in managing commercial activities" $\{27\}$ as well as disabled people $\{13\}$, specifically the visually impaired $\{47\}$.

This development of participation will lead to "greater opportunities for all" $\{3\}$. Part of the process will be increased transparency, for example in the banking industry $\{27\}$, as well as national and international solidarity $\{54\}$. A particular emphasis is given to freedom, especially the market freedom to do business and be successful, thereby overcoming the problem of poverty. Participation is to be supported by e-government which will "bring the benefits of the emerging global information society to the largest possible segment of the population" $\{19\}$ and allow for "community participation" $\{20\}$. Best of all, the potential of ICT is not something we will have to wait for much longer. "A fully functioning, effective Egyptian Information Society is now just around the corner" $\{53\}$.

\section{$5.2 \quad$ Limits of participation}

The emancipatory rhetoric of ICT and the information society is contrasted starkly by social realities. Political participation as an expression of empowerment is highly limited. Egypt officially claims to be a democratic system but the implementation of a "presidential republic" where the main power holder is nominated by the People's Assembly and then confirmed by referendum leaves little space for political freedom. Compared to other countries Egypt's political system may be relatively liberal and allow for limited opposition activities [67]. Egypt also seems set for a further course of political liberalization with the recent creation of a National Council for Human Rights, the appointment of the first female judge, the cancellation of state security courts [6]. Also, Egypt has traditionally allowed greater openness and accountability in political decisions than neighboring countries [28]. On 26 Feb 2005 President Mubarak announced a multi candidate election for the position of President in 2005. The election was widely regarded as fraudulent, leading to the imprisonment of Mubarak's main rival. Also, Egypt is still ruled under Emergency Law.

While the external political environment does not appear to be conducive to personal empowerment, a closer look at the policy itself shows that the empowering claims are not taken seriously and not followed through. The general gist of the policy document is one of top-down development of ICT applications most of which are geared for specific stakeholder groups. Of 256 claims which identify a stakeholder, 156 refer to the government itself. The large majority of the remaining stakeholder claims (71) refer to businesses. Citizens are only identified as stakeholders 20 times. And where they are recognised as stakeholders they are invariably seen as passive recipients of government services. In the 16 of the 17 cases where an omission of relevant stakeholders was identified, these missing stakeholders were the citizens. No input from citizens to the development of the information society is sought.

A strong example of this exclusion of citizens from empowering participation is the "e-government" section of the policy $\{19\}-\{23\}$. The focus of e-government 
is the efficient provision of services to citizens, and, more importantly, to investors. Citizen input or even e-democratic participative models are not considered. Where decisions have to be made which stakeholders will be served first, business invariably wins the day over citizens $\{23\}$. The analysis of the text allows the conclusion that e-government does not involve any influence on political decisions. Also, e-government is very much seen in terms of e-commerce with one of the case studies and success stories of e-government $\{22\}$ describing an online billing system. The problems of equating citizens and consumers [77] are generally ignored.

\subsection{Empowerment through education}

It has become conventional wisdom that, in order to participate in society and lead a fulfilled life, one needs a certain amount of education. The Egyptian ICT policy reflects this standpoint and uses ICT as a lever for improving the provision of education to its citizens. The e-learning initiative aims to provide equal opportunities for learning "regardless of age, gender, class, or geographical location" $\{15\}$. ICT is meant to improve all levels of education. On the most basic level it will "strengthen attempts to eradicate illiteracy" $\{17\}$ and "encourage people to overcome illiteracy" $\{18\}$. At the same time the provision of ICT facilities in schools and universities will improve the quality of learning. It will provide much-needed capacity of higher education and increase the "competitiveness of [Egypt's] graduates" $\{13\}$. Teaching technology will also allow continuing education and life-long learning. A specific emphasis is placed on teaching ICT skills as these are seen as important for the job market and for international competitiveness $\{11\}$.

The policy concedes that there are problems, most notably those of access, usage, skills $\{4\}$, but also the general level of literacy and overcrowding of the educational system. However, the very use of ICT is seen as the solution to these and the correct usage of technology in education will take care of them. In order to persuade students to learn ICT skills, the government has set up a Basic Skills Training Program which is available free of charge to every young Egyptian and is even linked to a stipend $\{17\}$. Additionally, the government has initiated several programs which are aimed at spreading ICT around the country in a manner that will guarantee access to technology for everyone interested $\{11\}$. International cooperation, for example with UK universities, will help overcome the shortage problem of higher education $\{17\}$.

\subsection{Limits of educational empowerment}

The Egyptian education system faces serious problems. The level of illiteracy in the Egyptian population is close to $30 \%$. Literacy is a concept that is hard to define, but literacy as a condition of participation in an information society is a multi-facetted competence that requires intensive educational effort [58]. It seems to be an unrealistic assumption that the mere provision of technology will solve 
the problem of illiteracy. It furthermore stands to reason that the introduction of ICT will produce more need for traditional education rather than alleviate pressure.

The Egyptian educational system is not well equipped to deal with the challenges of the information society. It performs poorly when compared to other developing countries, partly because of its bureaucratic structure and its outdated pedagogical model [86]. On top of this there is the demographic development with the number of secondary school graduates doubling from 375,000 to 650,000 from 2003 to 2005 alone and a further expected in crease to 800,000 in 2007 and $1,200,000$ by $2017\{13\}$. Even a perfect system would find it extremely hard to deal with this sort of challenge.

The solution outlined in the government policy, namely to leverage technology to solve the problem, will most probably not solve it. It is insensitive to contextual, political, and pedagogic issues. It concentrates on technical matters, most notably on the provision of equipment and technical access, which, at best, will be preconditions for a successful use of ICT. In the document on e-readiness entitled "The Way Forward" $\{12\}$, the government concentrates on technicalities of access provision that are so advanced that they would have little relevance even in the most developed societies. The concentration on technology allows sidestepping the more difficult social issues behind the education problem (Warschauer, 2003). Solutions are suggested, such as the use of schools as publicly accessible Internet cafes $\{15\},\{17\}$ which go counter to the established use of ICT. Finally, the literature on e-teaching and e-learning which suggests that the introduction of technology into education may introduce new problems (Stahl, 2004) is ignored.

ICT education, which is praised as a solution is in practice organised so that it is impossible for students to fail. Due to the lack of equipment, ICT education is often done theoretically without access to technology. And even where technology is available, it is often not made accessible to students because it is perceived as being too valuable [86]. The policy itself demonstrates that the government is not following through on its emancipatory promises. If education is to lead to empowerment, then one would expect that teachers and students as main stakeholders would have a say in its provision. However, rather than seeing students as active participants of education, they are passive recipients. Where stakeholders of education are explicitly named, we find the names of major corporations $\{17\}$. Education is not seen as an end in itself or as a means of empowerment but rather as a way to produce "human capital" and make Egypt attractive to foreign investment. Literacy or education are named relatively frequently as benefits of ICT (37 times) but this number pales in comparison to economic benefits, which are cited 110 times.

In general, the use of ICT is promoted as a way of solving the very serious problem Egypt is facing with regard to educating its rapidly growing population. However, the discourse concentrates on technical matters, thus leaving unexplored the more important underlying questions such as the purpose of education (cf. 
Sahay, 2004), the pedagogical fit of technology, and the greater social issues including illiteracy.

\subsection{Summary of findings}

The above description of the research findings supports the conclusion that the use of ICT in Egypt on the national level of the Information Society Policy is actively disempowering. There is a strong empowering rhetoric. This empowering rhetoric is an important aspect of the promotion of ICT because it lends legitimacy to the endeavour. This empowering promise of ICT is not kept. The Habermasian framework allowed me to identify contradictions between the rhetoric and the underlying intention. The critical discourse analysis demonstrated that the rhetorical validity claims are contradicted within the policy itself. The general gist of the policy document is one of one-sided economic liberalism that is fundamentally unconcerned with the individual empowerment.

\section{Reflections}

Critical research aims to be reflective. In order to live up to this standard, it needs to reflect on itself. Weaknesses, biases, alternatives and assumptions must be subject to critical reflection. This goes beyond the usual discussion of limitations and must question the heart of the research.

\subsection{Theory and methodology}

There are a number of questions one could raise about the use of concepts, theory and methodology in this piece of research. A visible omission of the chapter is the lack of a definition of "development". The term is contentious and divisive [30] and a discussion would add little to the chapter. Egypt is a developing country by most standards and the use of ICT is linked to efforts of development, however defined.

Another problematic aspect might be the use of theory. Does the chapter do justice to Habermas? A possible answer is that the question is of limited relevance for critical research. For critical research it is more important to follow the "emancipatory spirit than to the authoritative letter of any particular Critical Theorist" [3, p. 3]. Critical research is not a matter of applying a theory correctly but of using theoretical guidance to promote the critical intention [10, 83].

An important part of the critical reflection aims at clarifying the assumptions and biases the research is based on. The most important bias is that the argument was developed in the western tradition of thought whose applicability to Egypt is not obvious. This raises the difficult problem of the transferability of thoughts between cultures $[84,78,77]$. Without being able to argue this point conclusively here, I believe that the aim of emancipating and empowering people is universal and can be applied to non-western environments as well as to western ones. I concede that empowerment may take a different form in the Arab world than in 
the west. In order to accommodate this, I emphasized a concept of empowerment as employed by the Egyptian government itself.

\subsection{Exclusion of other stories}

By developing the present narrative I had to choose which aspects to discuss and which to neglect. This story therefore hides a multitude of other possible stories which may also be worth exploring. There are a few obvious candidates for alternative critical narratives of ICT use in Egypt. One of them is the international political order with its important influence on Egyptian politics. Western democracies seem to agree that peace and quite in the Middle East (again, a western description) is a political aim of high importance and they therefore stabilize the Egyptian government as best as they can. One can easily draw a line from Egyptian politics to the struggle of Israel and the Palestinians but also to other political developments in the Middle East. This, in turn is linked with questions of the desirability of certain types of government over others. There is an important connection to religious matters and the west's attempt to limit the political power of Islam. This, in turn is linked to the worldwide fear of terrorism, which influences western policies.

Another issue is that I have attempted to present the narrative in as linear and unequivocal a fashion as possible in order to make it more accessible to the reader. While I hope that I was successful in so doing, I realize that I may have neglected some important aspects. One of these is the concept of resistance. In the attempt to show that ICT is used for disempowerment I did not pay attention to the idea of resistance. Any Foucauldian scholar will know that for Foucault there is no power without resistance [36]. Space constraints precluded us from exploring these aspects. Critical research is never finished and always needs to be contextualized. I therefore believe that the omission of resistance and other observations counter to our narrative is justified by the fact that this chapter is only one contribution to a larger discourse.

Another omission is that of positive effects of ICT. This chapter has taken a negative stance and attempted to show that emancipatory rhetoric may hide oppressive agendas. This does not imply that all use of ICT in developing countries will always have to be oppressive or alienating. There are many good examples in the literature where ICT had emancipatory effects, either by design or by chance. Similar stories could be told about ICT in Egypt. The relationship between such cases of emancipation and the greater ICT policy is an issue worthy of further exploration.

\section{Conclusion}

In this chapter I have undertaken a critical discourse analysis of the Egyptian ICT policy with the aim of identifying claims to empowerment. These were then contrasted with other claims in the document as well as the social realities within 
which empowerment should take place. The outcome of the analysis is that empowerment is much cited in the policy, but that it is not followed through. There may be several explanations for this. One that I have argued for is that empowerment is used as a rhetorical device meant to create legitimacy for the policy despite a lack of real policy interest in empowerment. There are further explanations, which may interact and support the first one. Egypt finds itself faced by severe challenges, which render empowerment difficult to achieve in any circumstances.

This chapter should not be misunderstood as a contribution to conspiracy theories in general. I do not believe that there are large numbers of evil bureaucrats in the Egyptian government that conspire to keep the average Egyptian from reaching their potential (even though I cannot rule out that there are some of these, either). What I have tried to show is that there is a lack of sincerity when dealing with potentially empowering use of technology and that the policy document betrays this lack when analyzed in detail.

The chapter should not be misunderstood as implying that nothing good can come from the use of ICT in Egypt either. Whether intended or not, the use of technology tends to have results which are conducive to individual or collective emancipation. Even a strongly oppressive regime cannot avoid successful acts of resistance.

The purpose of the chapter is thus not to paint too bleak a picture but to point out that even a relatively high level analysis such as the one presented here can point to problems of aspirational texts such as the Egyptian policy. Researchers as well as practitioners are thus well advised to be careful when using such policy documents and to question the underlying beliefs, assumptions, and intentions. Critical research aims to promote emancipation. By questioning whether emancipatory claims are viable and consistent, I hope to have contributed to a continued discussion of the use of ICT in Egypt. I am sure that ICT can contribute to empowerment and emancipation in Egypt and elsewhere. But to be successful, such emancipatory aims must be taken more seriously than the Egyptian policy makers have arguably done. If this is accepted as a starting point, then the next and considerably more complex question will be how such emancipatory intentions can be implemented and what this will mean for developing as well as developed countries.

\section{References}

[1] Alvesson, M. \& Deetz, S. (2003). Doing critical management research, London: SAGE.

[2] Alvesson, M. \& Willmott, H (Eds.) (2003). Studying management critically, London: SAGE.

[3] Alvesson, M. \& Willmott, H (Eds.) (1992). Critical management studies, London: SAGE.

[4] Alvesson, M. \& Willmott, H. (1992). On the idea of emancipation in management and organization studies. Academy of Management Review, 17(3), 432 - 464. 
[5] anonymous. (2004). Two for TE? It's been an exciting year for the telecommunications industry. Annual Business Economic and Political Review: Egypt. available: www.oxfordbusinessgroup.com [accessed 01.11.2004], 125-128.

[6] anonymous. (2004). Wind of change - Egypt says it wants to reform, but how much? Annual Business Economic and Political Review: Egypt. available: www.oxfordbusinessgroup.com [accessed 01.11.2004], 23 - 24.

[7] anonymous (2004) Silicon Wadi - Egypt is making a bid to be the Arab world's IT hub, Annual Business Economic and Political Review: Egypt: available: www.oxfordbusinessgroup.com [accessed 01.11.2004], 129 - 130.

[8] anonymous (2004). Different Interpretations - Egypt and the United States share similar goals, but don't always see eye to eye, Annual Business Economic and Political Review: Egypt. Available: www.oxfordbusinessgroup.com [accessed 01.11.2004], $17-18$

[9] Apel, K. -O. (1988). Diskurs und Verantwortung: das Problem des Übergangs zur postkonventionellen Moral, Frankfurt: Suhrkamp.

[10] Avgerou, C. (2005). Doing critical research in information systems: some further thoughts. Information Systems Journal, (15),103 - 109

[11] Avgerou, C. (2003). The Link Between ICT and Economic Growth in the Discourse of Development, in M. Korpeal, R. Montealegre, \& A. Poulymenakou (Eds.), Organizational Information Systems in the Context of Globalization (pp. 373-386) Dordrecht: Kluwer.

[12] Avgerou, C., McGrath, K. (2007). Power, rationality, and the art of living through socio-technical change. MIS Quarterly, 31(2). 295-315.

[13] Bebbington, A., Guggenhein, E., Olson, E., Woolcock, M. (2004). Grounding discourse in practice: exploring social capital debates at the World Bank. Journal of Development Studies, 40(5), 33-64.

[14] Brett, E.A. (2003). Participation and accountability in development management. The Journal of Development Studies, 40(2), pp. 1-29

[15] Brooke, C. (2002). What does it mean to be 'critical' in IS research? Journal of Information Technology (17), 49 - 57

[16] Brooke, C. (2002). Critical perspectives on information systems: An impression of the research landscape. Journal of Information Technology (17), 271 - 283

[17] Burrell, G. \& Dale, K. (2003). Building better worlds?: Architecture and critical management studies, in Studying Management Critically, M. Alvesson, Mats \& H. Willmott (Eds.), (pp. 177 - 196), London`: SAGE.

[18] Cecez-Kecmanovic, D. (2001). Doing critical IS research: The question of methodology, in Qualitative Research in IS: Issues and Trends, E. Trauth (ed.), (pp. 141 - 162), Hershey: Idea Group Publishing.

[19] Cecez-Kecmanovic, D. (2001). Critical information systems research: A Habermasian approach. In: Proceedings of the 9th European Conference on Information Systems, Bled, Slovenia, June 27-29, 253-263

[20] Cecez-Kecmanovic, D.; Janson, M. \& Brown, A. (2002). The rationality framework for a critical study of information systems. Journal of Information Technology (17), $215-227$

[21] Chouliaraki, L. \& Fairclough, N. (1999). Discourse in late modernity - rethinking critical discourse analysis. Edinburgh: Edinburgh University Press.

[22] Chua, W. F. (1986). Radical developments in accounting thought. The Accounting Review 61(4), 601-632.

[23] Ciborra, C. (2000). A critical review of the literature on the management of corporate information infrastructure., in C. Ciborra, Claudio and Associates, From Control to 
Drift: The Dynamics of Corporate Information Infrastructures, (pp. 15 - 40), Oxford: University Press .

[24] Cukier, W.; Middleton, C.,\& Bauer, R. (2003). The discourse of learning technology in Canada: Understanding communication distortions and the implications for decision making, in E. Wynn; E. Whitley; M. Myers. \& J. DeGross (Eds.), Global and Organizational Discourse About Information Technology, (pp. 197 - 221), Dordrecht: uwer Academic Publishers.

[25] Cukier, W.; Bauer, R.,\& Middleton, C. (2003). Applying Habermas' validity claims as a standard for critical discourse analysis, in B. Kaplan; D Truex; T. Wood-Harper \& J. DeGross (Eds.), Information Systems Research - Relevant Theory and Informed Practice, (pp. 233-258), Dordrecht: Kluwer Academic Publishers.

[26] Dawson, R. J. \& Newman, I. A. (2002). Empowerment in IT education. Journal of Information Technology Education 1(2), 125-141.

[27] El Sayed, H. \& Westrup, C. (2003). Egypt and ICTs - how ICTs bring national initiatives, Global Organizations and local companies together. Information Technology \& People 16(1), 76-92.

[28] El Sherif, H. \& El Sawy, O. A. (1988). Issue-based decision support systems for the Egyptian cabinet. MIS Quarterly 12(4), 551-569.

[29] Elkjaer, B.; Flensburg, P.; Mouritsen, J. \& Willmott, H (1991). The commodification of expertise: The case of systems development consulting. Accounting, Management and Information Technologies 1(2), 139 - 156

[30] Escobar, A. (1995). Development, Princeton University Press, Princeton, NJ.

[31] Ess, C. (1996) Introduction: Thoughts along the I-way: Philosophy and the emergence of computer-mediated communication, in Philosophical Perspectives on Computer-Mediated Communication, Ess, C. (Ed.), (pp. 1 - 12), Albany: State University of New York Press.

[32] Fairclough, N. (2003) Analysing discourse - textual analysis for social research, London \& New York: Routledge.

[33] Fairclough, N. (1995) Critical discourse analysis - the critical study of language. London: Longman.

[34] Fairclough, N. (1993) Critical discourse analysis and the marketization of public discourse: the universities. Discourse \& Society (4:2), 133 - 168

[35] Forester, J. (1992) Critical ethnography: on fieldwork in a Habermasian way. In M. Alvesson \& H. Willmott (Eds.), Critical Management Studies, (pp. 4-65), London: SAGE.

[36] Foucault, M. (1975) Surveiller et punir: Naissance de la prison, Paris : Gallimard.

[37] Habermas, J. (1996) Die Einbeziehung des Anderen - Studien zur politischen Theorie, Suhrkamp, Frankfurt a. M.

[38] Habermas, J. (1981) Theorie des kommunikativen Handelns - Band I, Suhrkamp Verlag, Frankfurt a. M.

[39] Habermas, J. (1981) Theorie des kommunikativen Handelns - Band II, Suhrkamp Verlag, Frankfurt a. M.

[40] Harvey, L. (1990) Critical Social Research. London: Unwin Hyman

[41] Heng, M. S. H. \& de Moor, A. (2003) From Habermas's communicative theory to practice on the Internet. Information Systems Journal (13), 331-352.

[42] Hirschheim, R. \& Klein, H. K. (2003) Crisis in the IS field? A critical reflection on the state of the discipline. Journal of the Association for Information Systems 4(5), $237-293$.

[43] Hirschheim, R. and Klein, H. K. (1989) Four paradigms of information systems development, Communications of the ACM, 32(10), 1199-1216. 
[44] Howcroft, D. \& Trauth, E. M. (Eds.) (2005) Handbook of Critical Information Systems Research: Theory and Application. Cheltenham: Edward Elgar.

[45] Howcroft, D. \& Trauth, E. M. (2004) The choice of critical information systems research, in B. Kaplan, D. P. Truex, D. Wastell, A.T. Wood-Harper \& J. DeGross, Information Systems Research: Relevant Theory and Informed Practice (IFIP 8.2 Proceedings) (pp. 196 - 211), Dordrecht: Kluwer.

[46] Howcroft, D. \& Wilson, M. (2003) Paradoxes of participatory practices: the Janus role of the systems developer. Information and Organization 13(1), 1-24.

[47] ISDO, Information Society Development Office Mission Statement, available: http://www.isdo.gov.eg/mission.asp [accessed, 16.03.2005]

[48] Klein, H. K. \& Myers, M. D. (1999) A set of principles for conducting and evaluating interpretive field studies in information systems. MIS Quarterly 23(1), 67-94

[49] Klein, H. K. \& Huynh, M. Q, (2004) The critical social theory of Jürgen Habermas and its implications for IS research, in Mingers, J. \& Willcocks, L. (Eds.), Social Theory and Philosophy for Information Systems (pp. 157 - 237), Chichester: Wiley

[50] Klenow, P.J. \& RodrõÂguez-Clare, A. (1997) Economic growth: a review essay, Journal of Monetary Economics 40, 597-617.

[51] Kvasny, L.; Greenhill, A. \& Trauth, E (2005) Giving voice to feminist projects in MIS research. International Journal of Technology and Human Interaction 1(1), 1-18

[52] Kvasny, L. \& Trauth, E. (2003). The digital divide at work and home: The discourse about power and underrepresented groups in the information society, in E. Wynn, E. Whitley, M. Myers, \& J. DeGross (Eds) Global and Organizational Discourse About Information Technolog, (pp. 273 - 291), Kluwer Academic Publishers, Dordrecht

[53] Kvasny, L. \& Truex, D. (2000). Information technology and the cultural reproduction of social order: A research program, in: Baskerville, R.; Stage, J. \& DeGross, J. (Eds.) The Social and Organizational Perspective on Research and Practice in Information Technology. (pp. 277 - 293) Boston: Kluwer.

[54] Levy, D. L.; Alvesson, M. \& Willmitt, H. (2003). Critical approaches to strategic management, in in M. Alvesson, Mats \& H. Willmott (Eds.), Studying Management Critically (pp. 92 - 110), London: SAGE.

[55] Lyytinen, K. (1992). Information systems and critical theory, in M. Alvesson \& H. Willmott (Eds.), Critical Management Studies (pp. 159 - 180), London: SAGE.

[56] Lyytinen, K. \& Hirschheim, R. (1988) Information systems as rational discourse: an application of Habermas theory of communicative action, Scandinavian Journal of Management, 4(1/2), 19-30.

[57] Marx, K. (1969). Manifest der kommunistischen Partei, Reclam, Stuttgart.

[58] Mason, R. O. (1986). Four ethical issues of the information age. MIS Quarterly, 10, 5-12.

[59] McAulay, L.; Doherty, N. \& Keval, N. (2002). The stakeholder dimension in information systems evaluation. Journal of Information Technology, 17, 241 - 255

[60] McGrath, K. (2005) Doing critical research in information systems: A case of theory and practice not informing each other, Information Systems Journal, 15, 85 - 101

[61] Mejias, R.J., Palmer, J.W. \& Harvey, M.G. (1999) Emerging technologies, IT infrastructure, and economic development in Mexico. Journal of Global Information Technology Management 2(1), 31-54.

[62] Mingers, J. (1992) Technical, practical and critical OR - past, present and future? in Critical Management Studies, M. Alvesson \& H. Willmott (Eds.), (pp. 90-113) SAGE, London

[63] Montealegre, R. (1998) Waves of change in adopting the Internet: lessons from four Latin American countries. Information Technology \& People 11(3), 235-260. 
[64] Mubarak, H. (1999) Address by President Muhammad Hosni Mubarak to The National Conference on The Promotion of Technology and Information. Available: http://www.presidency.gov.eg/html/13_9.htm (accessed 16.11.2004), 13 Sep. 1999

[65] Mubarak, H (2000) President Mubarak's speech at the lunch hosted in his honor by Virginia's Governor. Available: http://www.presidency.gov.eg/html/27Mar2000_speech.htm (accessed 21.12.2004), 27 March 2000

[66] Ngwenyama, O. K. \& Lee, A. S. (1997) Communication richness in electronic mail: Critical social theory and the contextuality of meaning. MIS Quarterly 21(2), 145-167

[67] Nidumolu, S. R.; Goodman, S. E.; Vogel, D. R. \& Danowitz, A. K. (1996) Information technology for local administration support: The governorates project in Egypt. MIS Quarterly 20(2), 197-224.

[68] Orlikowski, W. J. \& Baroudi, J. J. (1991) Studying information technology in organizations: Research approaches and assumptions. Information Systems Research 2(1), 1-28.

[69] Probert, S. K. (2002) Ethics, authenticity and emancipation in information systems development, in A. Salehnia (Ed.), Ethical Issues of Information Systems (pp. 249254), Hershey: IRM Press.

[70] Sahay, S. (2004) Beyond utopian and nostalgic views of information technology and education: Implications for research and practice. Journal of the Association for Information Systems 5(7), 282 - 313

[71] Saravanamuthu, K. (2002) Information technology and ideology. Journal of Information Technology 17, 79 - 87

[72] Schuurman, F.J. (2003) Social capital: the politico-emancipatory potential of a disputed concept. Third World Quarterly, 24(6), 991-1010

[73] Settle, A. \& Berthiaume, A. (2002) Debating e-commerce: Engaging students in current events. Journal of Information Systems Education, 13(4). 279-285.

[74] Stahl, B. C. (2008) Information Systems: Critical Perspectives. Routledge, London

[75] Stahl, B. C(2008) The ethical nature of critical research in information systems. Information Systems Journal, Special Issue on Exploring the Critical Agenda in IS Research, edited by Carole Brooke, Dubravka Cecez-Kecmanovic, Heinz K. Klein, 137-163.

[76] Stahl, B. C. (2006) Emancipation in cross-cultural IS research: the fine line between relativism and dictatorship of the intellectual. Ethics and Information Technology 8(3), Special issue on Bridging Cultures: Computer Ethics, Culture, and Information and Communication Technologies, edited by Charles Ess, 97-108

[77] Stahl, B. C. (2005) The paradigm of e-commerce in e-government and e-democracy, in Huang, Wayne; Siau, Keng \& Wei, Kwok Kee (Eds), Electronic Government Strategies and Implementation (pp. 1 - 19), Hershey: Idea Group Publishing.

[78] Stahl, B.C. \& El Beltagi, I. (2004) Cultural universality versus particularity in CMC, Journal of Global Information Technology Management 7(4), 47-65

[79] Temple, J. (1998) The New Growth Evidence, Institute of Economics and Statistics, Oxford

[80] Thompson, M. (2003) ICT, power, and developmental discourse: A critical analysis, in: Global and Organizational Discourse about Information Technology, E. Wynn; E. Whitley; M. Myers. \& J. DeGross, (pp. 347 - 373) Kluwer Academic Publishers, Dordrecht

[81] Ulrich, W. (2001) A philosophical staircase for information systems definition, design, and development. Journal of Information Technology Theory and Application $(3: 3), 55-84$ 
[82] Varey, R. J.; Wood-Harper, T. \& Wood, B. (2002) A theoretical review of management and information systems Using a Critical Communications Theory. Journal of Information Technology 17, 229 - 239

[83] Walsham, G. (2005) Learning about being critical. Information Systems Journal (15), $111-117$

[84] Walsham, G. (2001) Making a World of Difference - IT in a Global Context. Wiley, Chichester

[85] Walsham, G. (1993) Decentralization of IS in developing countries: Power to the people? Journal of Information Technology 8, 74 - 81

[86] Warschauer, M. (2003) Dissecting the "digital divide": A case study in Egypt. The Information Society 19, 297 - 304

[87] White, G. (2006) Towards a democratic developmental state. IDS Bulletin, (37:4), 6071.

[88] Wilson, M. \& Howcraft, D. (2002) Re-conceptualising failure: social shaping meets IS research. European Journal of Information Systems 11, 236 - 250. 